\title{
COMPARATIVE ANALYSIS OF PUBLIC TELEVISION CHANNELS FOR CHILDREN IN EUROPE. THE CASE OF CBBC, RAI YOYO AND CLAN
}

\author{
Carmen Marta Lazo, María José Pérez-Serrano, Juan Pablo Artero Muñoz \\ Faculty of Philosophy and Letters - University of Zaragoza \\ cmarta@unizar.es \\ Faculty of Information Sciences - Complutense University of Madrid \\ mariajoseperezserrano@pdi.ucm.es \\ Faculty of Philosophy and Letters - University of Zaragoza \\ jpartero@unizar.es
}

\section{ABSTRACT}

\begin{abstract}
Television industrial organization is probably more complex than in other media industries. Reasons behind include that it is newer than others, it is highly regulated and because many changes have taken place in a short time period. In particular, public service television deserves an in-depth study. This is the starting point of this piece of research, which is applied to children as an audience of a growing complex and competitive market. In doing so, this study focuses on public service broadcasters of three European countries: the United Kingdom, Italy and Spain. A correlation analysis of these three cases will be made and the main hypothesis is that the content of all three channels and their audience profiles is quite similar. It will be implemented by Research Group on Digital Information and Communication (GICID, University of Zaragoza) and Research and Learning of Media and Communications Management (MediaCom, Complutense University of Madrid).
\end{abstract}

\section{Indexing terms/Keywords}

Content; audience; children;s television; United Kingdom; Italy; Spain

\section{Academic Discipline And Sub-Disciplines}

Communication Sciences; Media Business

\section{SUBJECT CLASSIFICATION}

UNESCO nomenclature for fields of science and technology: 531100: Organization and management of enterprises 630800: Social communications

\section{TYPE (METHOD/APPROACH)}

Correlation analysis of three cases

\section{Council for Innovative Research}

\section{Peer Review Research Publishing System}

Journal: Journal of Social Sciences Research

Vol .7, No.1

jssreditor.cir@gmail.com

www.jssronline.com 


\section{INTRODUCTION}

Among the main industries in the media market, organisation of television raises perhaps more complexity given the fast track changes that can be perceived if taken into account its evolution and regulation (Artero, 2008). In this occasion, public service broadcasters (PSBs) are studied. Moreover, the children audience is analyzed as a public within a more complex, competitive market. While combining both aspects, this piece of research is focused on PSBs children's TV channels in three European countries: United Kingdom, Italy and Spain.

Kids as a target audience are developing and adapting themselves to changes in behaviour and consumption patterns. Thanks to new platforms, children are watching more TV than ever, according to Johanna Karsenty (Kids TV Report, 2013). This report states than, during the first semester of 2013 , television consumption by children in five European countries (France, Germany, Italy, Spain and the United Kingdom) reached two hours and 14 minutes per day, which is an increase of five more minutes in the last five years. Moreover, online platforms understood that children represent tomorrow's consumption. Amazon, Hulu, iTunes, Netflix and Samsung are offering children programming, whether they are exclusive productions or purchased rights. New agents in the marketplace suppose new opportunities. Traditional broadcasters are seeking alliances so as to supply their programmes through different screens and platforms. Netflix has reached an agreement with DreamWorks, as well as Amazon with Nickelodeon. No doubt they are wise moves so as to multiply contacts with the youngest consumers (Eurodata TV Worldwide, 2013).

That trend is getting even stronger with the smart TV effect. Well known brands are distributing TV sets that can be connected directly to the Internet in order to provide audiences new interactive experiences, generally more sophisticated than proper MHP systems. This chance to access live, conventional TV content combined with on-demand consumption is arranging a new offer of audiovisual material for audiences that has been labelled as DTTcom (Franquet \& Ribes, 2010).

\section{LITERATURE REVIEW}

In the last decade, many publications have analyzed the relation between children and television from several perspectives: children programming (Cebrián Herreros, 2003; Vázquez, 2009; García Vega \& Torres Martín, 2009 : 103122; Fernández Gómez, 2012; Mateos Pérez, 2012); TV consumption by kids and teenagers (Ibañez, Pérez \& Zalbidea, 1999: 237-256; Pérez-Ornia y Núñez-Ladeveze, 2006, 133-177; Messenger Davies, 2001; Marta-Lazo, 2005a; García Matilla \& Molina, 2008: 83-90; Marta-Lazo \& Gabelas Barroso, 2008; López-Vidales, González-Aldea \& Medina, 2010: $97-$ 130); children content analysis (Álvarez, Del Río \& Del Río, 2003; Tur \& Grande, 2009: 33-59; López Sánchez, Tur-Viñes \& García del Castillo, 2010); as well as audiovisual literacy (García Matilla, 2005; Marta-Lazo, 2006; Aguaded \& SánchezCarrero, 2008; Buckingham, 2008; Ferrés \& Piscitelli, 2012: 75-82; Tolsá \& Bringué, 2012: 253-288; Marta-Lazo \& Grandío, 2013). In addition, other publications have adopted a more panoramic perspective (Marta-Lazo, 2005b; Del Río Alvarez \& Román Blas, 2005; Bringué \& Sádaba, 2008; Fernández Martínez et al, 2011; Ortiz, Ruiz \& Díaz, 2012).

Concerning audience research, the trend has also changed towards an increasing diversification of uses, consumptions and interactions coming from the plurality of screen options. Visualization is converging with other activities such as reading, shopping, voting, gaming, research, writing, or chatting. These media are now used in different ways, anywhere and anytime (Livingstone, 2004: 76).

Besides, it should be accounted as a key element in public service broadcasting, children TV programming has not always been considered as a priority (Pérez Serrano, 2010). However, factors like competition from US multinationals in the 1990s (Disney, Nickelodeon and Cartoon Network) and the online media increase have favoured that PSBs have invested in their own children TV channels and a substantial presence in the online world. Steemers (2012) points out that public service television must create theme channels for kids by using the latest technologies so as to accomplish its public service mission.

Particularly in Spain, channels tried a children programming with more quantitative than qualitative weight. In-house production spaces were low quality and very few and competition among channels motivated a uniform characteristic. Competition did not shape innovation or a rational planning so as to capture young audiences. On the contrary, improvisation motivated the elimination of some programmes, substitution for similar ones and a pretty unstable landscape that barely changed the TV supply (Mateos-Pérez, 2012: 544).

According to data from Barlovento (Vázquez Barrio, 2011: 74), generalist channels broadcasting on free to air television only included a $6,63 \%$ of children programming (ranging from La Sexta with $0,03 \%$ to La 2 with $13,54 \%$ ). Public service channels devoted more time than private operators. Most of the content was concentrated in the same time slot, namely at morning of weekend days. Children were not competitive for afternoon or evening slots, given that they were not considered part of the commercial target and their contents were incompatible with older audiences (Pérez Ornia \& Núñez Ladevéze, 2003). Because of that, TV channels did not have any interest in focusing their programming on children. They very much focused on reaching more profitable segments of society (Vázquez Barrio, 2011: 77).

However, with the arrival of DTT, this segment was considered again as an interesting target. As a consequence, La 2's children's programming was moved into a new theme channel, Clan TVE. Several channels found DTT an ally so as to satisfy that demand and diversify their business. Children and teenagers were considered a new target audience for old channels at the new theme screens. Jointly with Clan, Neox (Antena 3), Boing (Telecinco) and Disney Channel arrive to the market (Fernández Gómez, 2012: 313-314).

The former BBC's chief of children's programming Anna Homes raised at the House of Lords two critical issues. Firstly, she suggested that kids are watching too much American-produced content. Secondly, it is very important for children to have access to educational and social content which reflects their concerns and cultures (Steemers, 2012: 1). However, the British situation is quite exceptional due to the BBC's role with quality resources for children, not only for those in the UK but also as an important exporter to other countries. Especially regarding other English speaking countries, such as 
Australia and New Zealand. In fact, $85 \%$ of children's programming in UK's public service channels had a British origin (Ofcom, 2013).

Digital technology development has facilitated content diversification towards a new model with varied channels aimed at different population segments. Storsul and Syvertsen (2007: 87-88) point out the leading role of public service channels concerning digital development in the UK. Communications Act of 2003 regulated the distribution of new licenses and consolidated Ofcom, which guarantees control over changing technology development. The BBC made important investments on new digital radio and television channels. During 2002-2003, four new TV channels were launched, two of them aimed at children (CBBC and CBeebies), as well as BBC Three and Four.

BBC's digital channels can be received through Freeview platform, the decoder that permits access to DTT. In the case of TVE, these channels can also be received through cable and satellite. At the moment, both public corporations broadcast the same number of channels. However, TVE barely produces new content for digital channels, while most BBC programmes are brand new. The increase of TV supply in Spain and the UK motivated an audience decrease for both institutions. TVE lost 10,6 share points while BBC diminished by 7,6 (Medina \& Ojer, 2009: 277).

In Italy, analogue switch off took place on December 12 2012. As well as in Spain, children's programming was characterized by Japanese cartoons and containing programmes. With DTT, two news channels were created: RAI Gulp (children attending primary school) and RAI Yoyo (smaller/younger kids). While RAI Gulp is based on traditional programming such as documentaries, cartoons and active participation, RAI Yoyo is focused on games (Rossi, 2010).

\section{METHODOLOGY}

Our object of study is centred on children's TV channels operated by public service broadcasters in three European countries: United Kingdom, Italy and Spain.

Table 1. Studied children TV channels. Source: websites

\begin{tabular}{|c|c|c|c|}
\hline COUNTRY & CHANNELS & LAUNCHING DATE & TARGET \\
\hline \multirow{2}{*}{ UNITED KINGDOM } & CBEEBIES & \multirow{2}{*}{ February 112022} & $<6$ yo \\
\hline & CBBC & & $7-12$ yo \\
\hline \multirow{2}{*}{ ITALY } & YOYO & November 12006 & Pre-school kids \\
\hline & GULP & June 12007 & Primary school children \\
\hline SPAIN & CLAN & December 122005 & $\begin{array}{c}\text { 7-13 yo (some pre-school } \\
\text { content) }\end{array}$ \\
\hline
\end{tabular}

Three case studies analysis will be conducted, giving special emphasis to CBBC, RAI Gulp and Clan channels. So as to analyse programming, that of Thursday May 82014 in all three channels has been taken as an example.

The goal is determining to what extent content and audience are similar in all three cases. The basic hypothesis is that there are similarities among content and audience profiles of all three channels. In doing so, we will review reference literature such as the methodological contribution for children's programming analysis by Cebrián Herreros (2003).

\section{RESULTS}

\section{a) CBBC}

CBBC as a brand comes from Children's BBC. That brand was originally launched on September 91985 at BBC One. Later on it was produced as an independent channel in 2002. It is aimed at children between 6 and 12 years old, which complemented BBC One and BBC Two programming till January 2013. Till then, CBBC programming was similar to that on generalist channels, repeating series and some exclusive though minority content.

Currently, public service broadcasting is an important contribution for children with an essential component of public service mission. Producing national content and programming children's content in an increasing number of online channels is a function of the BBC Trust (Steemers, 2012: 1).

CBBC was launched on February 112002 and broadcasts between 7 am and 7 pm on DTT, as well as cable, satellite and IPTV. It shares the same band, though in a different position, than BBC Three. Its sister channel for smaller kids is CBeebies. CBBC's mission is providing a wide variety of diversified, quality content to children between 6 and 12 years old, including drama, entertainment, comedy, cartoons and news.

Table 2. CBBC Programming (May 8 2014). Source: CBBC

\begin{tabular}{|r|l|r|l|}
\hline \multicolumn{2}{|l|}{ Morning (am) } & \multicolumn{2}{|c|}{ Afternoon/Evening (pm) } \\
\hline $7: 00$ & Arthur & $11: 40$ & Arthur \\
\hline $7: 25$ & Dennis the Menace and Gnasher & $12: 05$ & Minuscule \\
\hline $7: 40$ & Newsround & $12: 10$ & Bear Behaving Badly \\
\hline $7: 45$ & The Dare Devil & $12: 30$ & All Over the Place: Australia \\
\hline
\end{tabular}




\begin{tabular}{|c|c|c|c|}
\hline $8: 15$ & Newsround & $12: 55$ & 60 Second Dennis \\
\hline $8: 25$ & The Story of Tracy Beaker & $1: 00$ & Roy \\
\hline $8: 40$ & Wingin' It & $1: 30$ & Leonardo \\
\hline 9:00 & The Legend of Dick and Dom & $2: 00$ & Style Download \\
\hline 9:30 & Jedward's Big Adventure & $2: 05$ & Tracy Beaker Returns \\
\hline $10: 00$ & Vip People & $2: 35$ & Hacker Time \\
\hline $10: 25$ & School for Stars & 3:05 & Arthur \\
\hline $10: 55$ & Turbo Boost & $3: 15$ & Minuscule \\
\hline $11: 25$ & OOglies & $3: 20$ & OOglies \\
\hline \multirow[t]{10}{*}{$11: 40$} & Arthur & 3:35 & Pet Squad \\
\hline & & $3: 50$ & Dennis the Menace and Gnasher \\
\hline & & $4: 00$ & What's New Scooby Doo? \\
\hline & & $4: 25$ & Newsround \\
\hline & & $4: 30$ & Splatalot \\
\hline & & $5: 00$ & Dani's Castle \\
\hline & & $5: 30$ & Blue Peter \\
\hline & & $6: 00$ & Scooby Doo! Mystery Incorporated \\
\hline & & $6: 25$ & The Story of Tracy Beaker \\
\hline & & $6: 50$ & Newsround \\
\hline
\end{tabular}

CBBC aims to paying attention to learning, with an emphasis on audience participation. As part of the original obligations for the channel, it had to broadcast 100 hours per year of educational programmes. That was reached by introducing the containing programme Class TV, at which educational content was broadcasted for two hours a day in the morning, while regular programming was aired in the afternoon. Many of these programmes were re-diffusions of old BBC School content. In some cases they were produced decades ago and few original programmes were created. CBBC was awarded as channel of the year at Children's BAFTA Awards in November 2008.

On the topic of audience, it must be highlighted that both CBBC and CBeebies keep being/continue to be the most watched channels by children in the UK. In 2012-2013, CBBS had a weekly reach of 36\% of children between 6 and 12 years old, a considerably higher figure than that of Disney Channel (22\%) and CITV (21\%). CBeebies currently reaches $48 \%$ of its target audience. However, loyalty index is lower in households that have cable and satellite services. Consumption of Disney channels is an important competition there and sometimes is higher than those of the BBC (Ofcom, 2013).

Apart from quantitative data, parents make a positive valuation of quality of BBC channels. CBBC and CBeebies receive high marks by parents and carers. $81 \%$ of them perceived them as high quality and diversified programmes, in particular in fiction and information, so as to reach a balanced equilibrium of education and entertainment. In addition, children value especially how education and information services are amusing and tell what is going on in the world in a clear and understandable manner.

In the last few years, CBBC has increased its accessibility to the public through its website, which includes a wide variety of activities, such as games, videos, music podcasts and news. In addition, it contains a TV guide with content from all programmes. It can be programmed in advance so as to be watched on an iPlayer during 29 days, which facilitates watching downloads from the channel's content.

According to BARB data (January 1 2005- July 8 2012), out of the top ten most watched programmes at CBBC, six of them were episodes of series The Sarah Jane Adventures and four were of series Tracy Beaker Returns. The audience figure was between 824,000 and 993.000. Concerning BBC's digital services, they have supposed a significant role in the increasing interest of consumers (losifidis, 2005: 57).

As Livingstone (2004: 76) points out, multimedia convergence is important in a model where the BBC expect to keep connecting communities or being a facilitator for online interest communities. That permits inviting a variety of publics, both local and global, accordingly to their specific interests, throughout a variety of platforms, including radio and the Internet. According to Ofcom Annual Report (2013), children's media consumption habits are changing due to technological development. In 2012, around one out of seven children between 5 and 15 years old used a tablet, which has tripled since 2011. An increasing number of children have also access to smart mobile telephones. In $2012,28 \%$ of children between 5 and 15 years old had a smart phone, in comparison with $20 \%$ in $2011.62 \%$ of children between 12 and 15 years old had it in 2012 , in comparison with $41 \%$ in 2011 . Children are increasingly interested in downloading programmes. For instance, in the first four months of 2013 the BBC iPlayer received an average of 10,8 million downloads of children content per week, in comparison with 6,6 million in 2012.

Besides that, Ofcom (2013: 30) research confirms the important role that traditional TV keeps playing on children's leisure time, especially for the smallest/youngest ones. In that sense, it keeps being the activity that most children declare to do on a daily basis. That suggests that online watching is additional or complementary to TV watching, tough an exponential growth is taking place.

Consequently, online website services are added to traditional TV watching. CBBC's website reached an average of 927,000 downloads in $2012-2013$, which represents an increase of $8 \%$ to previous year. CBeebies' website had 824,000 
unique visitors per week in 2012-2013. Moreover, the audience consider CBBC and CBeebies among the top ten quality websites. Parents highlight its high educational value. BBC's children's channels have put much attention on innovation and interactive online services, as well as applications for mobile devices (Ofcom, 2013).

\section{b) RAI Gulp}

In Italy, satellite TV supplies a high number of programmes so that the children audience can organise a whole programming with products especially designed for them (Cava, 2006: 20). Untill April 2007 there were several channels devoted to children's theme needs: Jim Jam, Animal Planet, Cartoon Network, Cartoon +1, Boomerang, Raisat Yoyo, Raisat Smash, Nickelodeon, Playhouse Disney, Disney Channel, Disney Channel +1, Jetix, Cultoon.

RAl offers two children's channels devoted to different audience profiles: pre-school (RAI YoYo) and primary school kids (RAI Gulp). It demonstrates the commitment towards that public segment, difficult to find among other European countries apart from the UK and the BBC (OssCom, 2013).

RAI Gulp was launched on June 12007 with a limited programming for satellite and DTT till 11pm, which was increased till the end of the day by June 2009. Between October 272008 and May 17 2010, only through DTT, a RAI Gulp channel was broadcasted with an hour delay (RAI Gulp +1 ), but it only lasted a year and a few months.

From April 27 2010, programming is coordinated from the RAI Ragazzi structure. The current channel logo has been used since May 18 2010. The channel is aimed at children between 6 and 10 years old. RAl Gulp programmes all genres, from cartoons series to live action, as well as magazines, documentaries and movies. Its sister channel, RAI YoYo is aimed at children between 0 and 8 years old and it has original formats and cartoons series.

Table 3. RAI Gulp programming (May 8 2014). Source: RAI Gulp

\begin{tabular}{|c|c|c|c|c|c|}
\hline \multicolumn{2}{|r|}{ Morning } & \multicolumn{2}{|r|}{ Afternoon/Evening } & \multicolumn{2}{|r|}{ Night } \\
\hline $6: 15$ & Lucky Fred & $13: 25$ & Kung Fu Panda & $20: 20$ & Big Time Rush \\
\hline $6: 30$ & Winx Club & $13: 50$ & Kung Fu Panda & $20: 40$ & Big Time Rush \\
\hline 7:00 & Winx Club & $14: 15$ & Grachi & $21: 10$ & Winx Club \\
\hline $7: 25$ & Le Nuove Avventure Di Peter Pan & 15:00 & Life With Boys & $21: 35$ & Winx Club \\
\hline $7: 50$ & Le Nuove Avventure Di Peter Pan & $15: 25$ & Life With Boys & $22: 00$ & Winx Club \\
\hline $8: 15$ & Kung Fu Panda & $15: 55$ & Ultimate Spiderman & $22: 25$ & Kung Fu Panda \\
\hline $8: 40$ & Kung Fu Panda & $16: 20$ & Ultimate Spiderman & $22: 50$ & Kung Fu Panda \\
\hline 9:05 & $\begin{array}{l}\text { Le Straordinarie Avventure Di Jules } \\
\text { Verne }\end{array}$ & $16: 45$ & Tiggi' Gulp 2013-2014 & 23:15 & Le Nuove Avventure Di Peter Pan \\
\hline 9:30 & $\begin{array}{l}\text { Le Straordinarie Avventure Di Jules } \\
\text { Verne }\end{array}$ & $17: 05$ & Kung Fu Panda & 23:40 & Le Nuove Avventure Di Peter Pan \\
\hline $10: 00$ & Kim & $17: 30$ & Kung Fu Panda & 0:05 & Mia And Me \\
\hline $10: 25$ & Kim & $17: 55$ & Winx Club & $0: 30$ & Mia And Me \\
\hline $10: 55$ & Kung Fu Panda & $18: 20$ & Gulp Girl 2013/2014 & $0: 55$ & Split \\
\hline $11: 20$ & Kung Fu Panda & $18: 45$ & House Of Anubis & $1: 20$ & Split \\
\hline $11: 45$ & $\begin{array}{l}\text { Le Straordinarie Avventure Di Jules } \\
\text { Verne }\end{array}$ & $18: 55$ & House Of Anubis & $1: 45$ & Gulp Girl 2013/2014 \\
\hline $12: 10$ & Le Nuove Avventure Di Peter Pan & 19:05 & House Of Anubis & $2: 05$ & Le Nuove Avventure Di Peter Pan \\
\hline $12: 35$ & Mia And Me & 19:15 & House Of Anubis & $2: 30$ & Kung Fu Panda \\
\hline $13: 00$ & Mia And Me & $19: 30$ & Violetta & $2: 55$ & Kung Fu Panda \\
\hline & & & & $3: 20$ & $\begin{array}{l}\text { Le Straordinarie Avventure Di Jules } \\
\text { Verne }\end{array}$ \\
\hline & & & & $3: 45$ & $\begin{array}{l}\text { Le Straordinarie Avventure Di Jules } \\
\text { Verne }\end{array}$ \\
\hline & & & & $4: 10$ & Kim \\
\hline & & & & $4: 35$ & Kim \\
\hline & & & & 5:00 & Kung Fu Panda \\
\hline & & & & $5: 25$ & Kung Fu Panda \\
\hline & & & & $5: 50$ & $\begin{array}{l}\text { Le Straordinarie Avventure Di Jules } \\
\text { Verne }\end{array}$ \\
\hline
\end{tabular}

RAI Gulp mostly broadcasts European cartoons series. Other classical series have been also aired, as well as cartoons movies on Sundays. During summer holidays in 2013 they also programmed some Disney films. An example of daily programming can be found on table 3 .

Audience figures by Auditel highlight that the higher share was reached in March 2010 with a 1,92\% of total television audience. These results were due to the channel's novelty, as far as consumption was later reduced considerably. In 2013, the average share was around 0,4\%, higher than in the two previous years. It must be considered that these figures should be added to those of RAI YoYo, which broadcasts programming for children between 0 and 8 years old with 
cartoons, fiction, stories and original productions, where educational content is offered. RAI YoYo accounted for around $1,3 \%$ of the audience share in 2013 . It can be pointed out that the audience is increasing, as far as it was around 0,3 or $0,4 \%$ in 2010 .

The abundant supply of children TV channels in Italy, both public and private, makes targets more segmented accordingly to ages: 14 channels for kids between 7 and 14 years old; seven between 3 and 6; and one for babies between 0 and 3 years old. Because of that, audience share is notably reduced, given that it is distributed among all children-oriented channels.

According to an Osscom report (2013), positive signals can be identified regarding experimentation within the educationentertainment axis. Pre-school programming is mostly cartoons series and it is characterised by a strong educational seal. It is precise to value in particular the participation and interactive dimension throughout narrative schemes that try to involve the public. The primary school programming is more complex because is less specific and it is opened to a wider target. That leads to dispersion, mostly among all young and adult TV offer in an optic of true and proper teenager-isation of TV supply.

\section{c) Clan TV}

Clan was launched on December 12 2005. Its offer was aimed at children between 7 and 13 years old. Among its programmes, some awarded educational series must be pointed out, such as Pocoyó and Dora, la exploradora (Explorer Dora).

Programming is characterised by the scarce Spanish-produced content, while there is a special interest in including series from European markets (mostly France, Italy and the UK). In doing so, programmers can assure a socio-cultural correspondence between Clan's public and its content arrangement. On the other hand, they try to reduce at minimum programmes coming from the biggest international markets, i.e. USA and China/Japan (Moreno Rodríguez, 2009: 7).

According to an analysis of Clan's programming carried out by Fernández Gómez (2012: 319), Clan has inherited part of La 2's content, such as Los Lunnis, Pocoyó, Caillou and Berni. In addition, it purchases many international series in comparison to the very few cases of in-house produced content or Spanish-independently created programmes. Half of the programmes share an entertainment goal (28 of them), while others are more educational (22 of them). In fact, educational content is mostly aimed at pre-school kids, who have 16 available programmes for them.

Table 4. Clan programming (May 8 2014). Source: Clan

\begin{tabular}{|c|c|c|c|c|c|}
\hline \multicolumn{2}{|r|}{ Morning } & \multicolumn{2}{|r|}{ Afternoon/Evening } & \multicolumn{2}{|r|}{ Night } \\
\hline $6: 17$ & Caillou & 13:18 & La brigada mascota & $19: 38$ & Las tortugas ninja \\
\hline $6: 39$ & Peppa Pig & $13: 40$ & Victorious & $20: 00$ & La invasión del plancton \\
\hline 7:00 & Tree Fu Tom & $14: 04$ & Victorious & $20: 21$ & La oveja Shaun \\
\hline 7:22 & La abeja Maya & 14:28 & Slugterra & $20: 29$ & Bob Esponja \\
\hline $7: 45$ & Dora la exploradora & $14: 49$ & Bob Esponja & $20: 52$ & Bob Esponja \\
\hline $8: 10$ & Bob Esponja & $15: 12$ & Los Pingüinos de Madagascar & $21: 15$ & Los Pingüinos de Madagascar \\
\hline $8: 33$ & Los Pingüinos de Madagascar & 15:35 & Dino Tren & $21: 38$ & Bob Esponja \\
\hline $8: 56$ & La brigada mascota & 16:02 & Sam el bombero & 22:01 & Victorious \\
\hline $9: 18$ & Los Lunnis & $16: 21$ & El armario de Chloe & $22: 25$ & Victorious \\
\hline 9:30 & Noddy & $16: 42$ & Tree Fu Tom & $22: 49$ & La invasión del plancton \\
\hline $9: 51$ & Pocoyó & 17:04 & La abeja Maya & $23: 10$ & Las tortugas ninja \\
\hline 10:06 & Peppa Pig & $17: 27$ & Peppa Pig & $23: 32$ & Los Pingüinos de Madagascar \\
\hline $10: 25$ & El armario de Chloe & $17: 46$ & Caillou & $23: 54$ & Slugterra \\
\hline $10: 46$ & La oveja Shaun & 18:10 & Matt Hatter Chronicles & & \\
\hline $10: 53$ & Chuggington & 18:32 & Bolts i Blip & & \\
\hline $11: 03$ & Chuggington & $18: 55$ & Pokémon & & \\
\hline $11: 14$ & Canimals & 19:17 & La brigada mascota & & \\
\hline $11: 21$ & La abeja Maya & & & & \\
\hline $11: 45$ & Gombby & & & & \\
\hline $12: 10$ & Las tortugas ninja & & & & \\
\hline 12:32 & Los Pingüinos de Madagascar & & & & \\
\hline 12:56 & Pokémon & & & & \\
\hline
\end{tabular}

Los Lunnis is one of the quality programmes at Clan, a containing space that combines educational content and social values with entertainment (García Vega y Torres Martín, 2009: 120). Clan reached an agreement with the National Institute for Communication Technology (Inteco) so as to/in order to broadcast messages of safe habits on the Internet, as well as pieces of advice for parents and tutors. Because of that, Clan created Las aventuras de Pipo y Mosi (Pipo and Mosi's Adventures) and Nicky y sus amigos (Nicky and his friends). Both are aimed at rising children's awareness of possible threats on the net so as to avoid them. 
Among educational content, science, nature and arts documentaries can be found. It can also be highlighted the interest for the learning of the English language. In the summer of 2013, programme Let's Clan was created and some series started to be broadcasted in their original language, such as Peppa Pig and Los Lunnis' section Work and play.

Besides that, lots of external production programme can be identified from a mere entertainment perspective. Because of that, Ortiz, Ruiz and Díaz (2013: 143) proposed a joint reflection between public service television and universities in order to reformulate Clan's programming. The basic goal would be turning it into a true educational and experimental channel focused on children and teenagers so as to justify one of the main senses of public service television: education and shape of critical citizens.

Concerning audience, Clan has been able to be one of the most watched theme channels in Spain. Audience share has gone from 1,3\% in January 2007 to 2,2\% March 2014. However, in the last few years a significant decrease has occurred. In 2011 audience share was 3,2\%; 2,5\% in 2012 and 2,3 in 2013. It can be observed a relative trend of migration of children to other screens.

Additionally, part of the content offer is now put on the Internet. As Fernández Gómez (2012: 321-322) states, Clan has an Internet portal where children can find their favourite content. Moreover, the website offers other services such as games. TVE launched Clan children's portal in June 2009. This migration trend to the Internet implies that TV channels must have an eye on it if they do not want this audience to be definitely migrating to computer screens or building their own programming by themselves.

Moreno Rodríguez (2008: 81-96) reached similar conclusions in a Delphi prospective piece of research on DTT and children's programming. Panel members perceived on children's DTT a more quantitative than qualitative contribution, considering that it offers similar content to that in the past, does not pay attention to the school curriculum and includes few changes. Regarding the effectiveness of interactive DTT systems, most of them saw interactivity as a facilitator of a more critical, personalized television consumption so as to promote children's communication and socialization.

\section{CONCLUSION AND DISCUSSION}

All public service European channels, including Clan, purchase international productions. As an exception, the BBC promotes in-house production that can export to other countries, especially English speaking ones. Both RAI Gulp and Clan favour broadcasting of European cartoons.

While the BBC pays much attention to educational programmes as a public service premise, RAI and TVE have a more diversified programming. They do not promote in such an extent educational content, which is clearly a minority.

BBC's information contents are produced in a clear and understandable manner for children. They are highly considered by parents and carers, given that it is a proper way for children to know what happens in the world. However, Clan and RAl Gulp do not include such essential spaces in their programming.

None of the analyzed channels make a bet for teenagers content. In fact, the BBC shut down in December 2010 BBC Switch, its teenager-oriented offer for children between 12 and 15 years old. Neither RAI nor TVE include that target specifically in their programming. Given that lack of attention by public service channels and the intensive use of new devices by teenagers, they are migrating towards other contents and services available through tablets and mobile phones. One of the challenges that BBC raises for 2017 is a plan so as to attend under-16 population throughout online radio and television services.

Regarding the most watched content, cartoons continue to be the top preference and represent more than $60 \%$ of the top 20 products in all three countries. Meanwhile, drama series are becoming increasingly popular. Non-fiction programmes dominate the ranking in the United Kingdom. Italian and Spanish children prefer modern classics from the US, such as Sponge Bob (TF1, Boing, Clan), Madagascar penguins (Boing, Clan) and Explorer Dora (TF1, Clan). Wolfblood, coproduced by BBC and German ZDF, is very successful in Disney Channel on Spanish DTT.

Among drama series, Disney's Violeta keeps being one of the top programmes in Italy (RAl Gulp) and Spain (Disney Channel). In the UK, factual programmes are a success with 12 titles among the top 20. The most important ones are Officially Amazing, Marrying Mum and Dad and Disaster Chefs, all of them from CBBC. That kind of offer has helped CBeebies to increase its audience share by 1,9\% among children between 4 to 6 year old (Eurodata TV Worldwide, 2013). One of the main indicators that rule the good functioning of public service television is content diversity for all publics, taking into account several age segments. Generalist TV channels have surrendered that premise to the new multi-theme platforms, with specialized channels whose offer is frequently externally produced and reiterative.

Convergence between television and the Internet permits children channels new interactive options, such as forums, chats or interactive games. These new possibilities are a complement to TV programming, which can be downloaded everywhere and anytime to give birth to new self-programming options. Because of that, new screens such as laptops, tablets and mobile phones enlarge chances to consume children TV content. In fact, these new devices take a stake year by year to traditional TV set, which is increasingly loosing children audience. In that sense, all channel would must pay more attention to website content and develop more multiplatform products for smart TV sets, computer and mobile phones, just like the BBC is doing.

Besides the social awareness on the importance of taking care of children's TV content, channels have tended to underattend that segment because programmes are seen as expensive and not profitable. As Del Río and Román (2005: 21) point out, they should pay attention to independent producers such as US-based Children TV Workshop (Sesame Workshop nowadays), which with initial subsidies reached a high profitability by selling and distributing quality audiovisual children's content and merchandising. In that sense, so as to promote quality children's programming it would be necessary to adequately fund public service television and other cultural institutions in order to research new formats, contents, projects, and personnel training for children's audiovisual products. High quality educational content is a key aspect of public service broadcasting that should be promoted within children's TV channels.

Attention should be paid to experimental spaces that might combine children's development and educational goals with 
entertainment, so as to reach commercial success. It is also important to wide internal production in order to promote cultural identity and values of each country. The same thing holds true with producing children-adapted newscasts, which permit them not to be separated from current affairs, as the BBC does.

As it has been highlighted in other pieces of research (Marta Lazo, 2005; Gabelas Barroso y Marta Lazo, 2008), television is an important children socialization agent. If it is used as an educational instrument jointly with schools and families, it can be useful so as to better promote personal and social development of new generations.

\section{REFERENCES}

[1] Artero Muñoz, J.P. 2008. El mercado de la televisión en España: Oligopolio. Barcelona. Deusto.

[2] Aguaded, J.I., and Sánchez-Carrero, J. 2008. "Niños y adolescentes tras el visor de la cámara: experiencias de alfabetización audiovisual”. Estudios sobre el Mensaje Periodístico, 14, 293-308.

[3] Álvarez, A., Del-Río, M., and Del Río, P. 2003. "El efecto Pigmalión en televisión: Orientaciones propuestas sobre la influencia de la televisión en la infancia. Red Digital”, 3. Retrieved from: http://reddigital.cnice. mec.es/6/Articulos/articulo_resumen.php?articulo=6 (10-05-2012).

[4] Bringué, X., and Sádaba, Ch. (coord.) 2008. La generación interactiva en Iberoamérica. Niños y adolescentes ante las pantallas. Madrid. Ariel.

[5] Berné Manero, C., García Uceda, M.E., and Orive Serrano, V. 2013. "Determinantes del comportamiento de consumo de televisión: un modelo estructural". Revista Mediterránea de Comunicación, 4, 2, 209-224. Retrieved from: http://www.mediterranea-comunicacion.org/Mediterranea/article/view/88/178

[6] Buckingham, D. 2008. Más allá de la tecnología. Aprendizaje infantil en la era de la cultura digital. Buenos Aires. Manantial.

[7] Cava, A. 2006. "Children Between Analogic and Digital TV: The Italian Case". Working Paper, 24. Quaderni del CIRSDIG. Universitá Studi di Messina.

[8] Cebrián Herreros, M. 2003. "Contenidos infantiles en televisión. Nueva técnica analítica global2. ZER, 15, 51-65. Retrieved from: http://www.ehu.es/zer/es/hemeroteca/articulo/contenidos-infantiles-en-television-nueva-tecnicaanalitica-global/205.

[9] Del Río Álvarez, M., and Román Blas, M. 2005. Programación Infantil de Televisión: Orientaciones y Contenidos Prioritarios. Madrid: Ministerio de Trabajo y Asuntos Sociales, RTVE e IORTV.

[10] Eurodata Tv Worlwide 2013. Aumenta el consumo televisivo entre los pequeños europeos. Retrieved from: http://www.audiovisual451.com/aumenta-el-consumo-televisivo-entre-los-pequenos-europeos/

[11] Fernández Gómez, E. 2012. "La programación infantil y juvenil de la televisión pública española: ¿oferta generalista o temática? El paso de La 2 a Clan TVE”. Estudios sobre el mensaje periodístico. 18, num. sp. Oct., 313-323. Madrid, Servicio de Publicaciones de la Universidad Complutense.

[12] Fernández Martínez, P. et al. 2011. Los niños y el negocio de la televisión. Programación, consumo y lenguaje. Salamanca: Comunicación Social.

[13] Ferrés, J., and Piscitelli, A. 2012. "La competencia mediática: Propues ta articulada de dimensiones e indicadores". Comunicar, 38, 75-82. (DOI http://dx.doi.org/10.3916/C38-2012-02-08).

[14] Franquet, R., and Ribes, F. X. 2010. "Los servicios interactivos. Una asignatura pendiente de la migración digital". Telos, 84.

[15] García-Matilla, A. 2005. “Por una televisión para la educación en sintonía multimedia”. Comunicar, 25, 33-44.

[16] —, and Molina Cañabate, J. P. 2008. "Televisión y jóvenes en España”, Comunicar, 31, 83-90.

[17] García Vega, R., and Torres Martín, C. 2009. "El vínculo infancia-televisión en la sociedad actual. Análisis de la programación infantil española”. Enseñanza y Teaching, 27, 103-122.

[18] Ibáñez Serna, J. L.; Pérez Fuentes, J. C., and Zalbidea Bengoa, B. (1999). Televisión y programación infantil en Euskadi. ZER, ำ 7, 237-256.

[19] Iosifidis, P. (2005). Digital Switchover and the Role of the New BBC Services in Digital Television Take-up. Convergence, 11, 3, 57-74.

[20] Livingstone, S. 2004. Researcher to Do in the Age of the Internet? The Challenge of Changing Audiences: Or, What is the Audience. European Journal of Communication, SAGE Publications. London, Thousand Oaks, CA and New Delhi, 19, 75-86.

[21] López-Sánchez, C.; Tur Viñes, V., and García Del Castillo J. A. 2010. "Evaluación del protagonista-antagonista en los contenidos audiovisuales dirigidos a la infancia en cadenas de televisión españolas". Revista Latina de Comunicación Social, 65. Retrieved from: www.revistalatinacs. org/10/art3/918_Alicante/40_Tur.html (DOI: 10.4185/RLCS-65-2010-918-553-560). 
[22] López-Vidales, N.; González, P., and Medina E. 2010. "Jóvenes y televisión en 2010: un cambio de hábitos". Zer, 16, 30, 97-130.

[23] Marta-Lazo, C. 2005a. La televisión en la mirada de los niños. Madrid. Fragua.

[24] -2005b. "Agentes mediadores y responsables del consumo infantil de televisión: familia, escuela y medios de comunicación". Comunicación y Hombre, 1, 19-33. Retrieved from: http://ddfv.ufv.es/handle/10641/815.

[25] -2006. "La guía paterna en el consumo televisivo: un modelo cuantitativo y cualitativo en el aprendizaje de contenidos". Ámbitos, 15, 211-221. Retrieved from: http://grupo.us.es/grehcco/ambitos\%2015/Ambitos15.pdf.

[26] - , and Gabelas Barroso, J. A. 2008. "La televisión: epicentro de la convergencia entre pantallas". Revista Enla@ce, año 5, 1, 11-23. Retrieved from: http://scholar.google.es/scholar?oi=bibs, andhl=es, andcluster $=2738035126533821807$.

[27] - , and Grandío, M. 2013. "Análisis de la competencia audiovisual de la ciudadanía española en la diimensión de recepción y audiencia”, Communication andSociety/Comunicación y Sociedad, 26, 2, 114 - 130. Retrieved from: http://dspace.si.unav.es/dspace/handle/10171/35487.

[28] Mateos-Pérez, J. 2012. "La programación infantil y juvenil en el cambio de ciclo televisivo español (1990-1994)". Palabra Clave, 15 (3), 524-548.

[29] Medina, M., and Ojer, T. 2009. "Valoración del servicio público de televisión. Comparación entre la BBC y TVE". Revista Latina de Comunicación Social, 64, 275-299.

[30] Messenger Davies, M. 2001. Children, Television Storytelling and the Public Sphere. Cambridge. United Kingdom at The University Press.

[31] Moreno Rodríguez, Mª D. 2008. "La TDT: el gran contenedor infantil del futuro". Enseñanza, 26, 81-96.

[32] -(2009). "La TDT impulsa la multiplicación de canales infantiles". EDUTEC. Revista Electrónica de Tecnología Educativa, 28, 1-14.

[33] OFCOM 2013 - 2012. Public Service Broadcasting Annual Report, Section B, PSB Audience Impact. Reino Unido. Ofcom London.

[34] Ortiz, M. A.; Ruiz, J.A., and Díaz, E. 2013. "Las televisiones y la investigación en infancia y televisión”. Comunicar, 40, 137-144.

[35] Osscom 2013. Tv per bambini, in Italia offerta 'chiusa' e a 'due velocità'. Si rischia divario economico-culturale? Retrieved from: http://www.key4biz.it/News/2013/09/30/Contenuti/Tv_per_bambini_children_s_tv_rai_mediaset_sky_iptv_cubovisio n_telecom_italia_220134.html.

[36] Pérez Serrano, M.J. 2010. "Discurso, identidad y publicidad en TVE. De lo periodístico a lo gerencial". Sphera Pública, 10, 139-151.

[37] Rossi, S. 2010. II servizio pubblico e la tv per bambini: analisi di RAI Gulp e RAI Yoyo, due canali RAI per il digitale terrestre. Università Cattolica del Sacro Cuore di Milano. Retrieved from: http://www.tesionline.it/consult/indice.jsp?pag=1, andidt=32258.

[38] Steemers, J. 2012. "Evaluating the contribution of public service broadcasters to children's media: The case of home-grown content” Paper for the RIPE@2012 Conference: Value for Public Money - Money for Public. Value, Sydney, 5-7 September 2012.

[39] Storsul, T., and Syvertsen, T. 2007. The Impact of Convergence on European Television Policy. Convergence: The International Journal of Research into New Media Technologies, 13 (3), 275 - 291.

[40] Tolsá, J., and Bringué, X. 2012. Leisure, interpersonal relationships, learning and consumption: the four key dimensions for the study of minors and screens. Comunicación y Sociedad, 1, 253-288.

[41] Tur, V., and Grande, T. 2009. Violencia y prosocialidad en los contenidos televisivos infantiles visionados por menores en Alicante. Zer, 27, 33-59.

[42] Vázquez Barrio, T. 2011. "La oferta televisiva para el público infantil: evolución y situación actual. In Fernández Martínez, P. et al.: Los niños y el negocio de la televisión. Programación, consumo y lenguaje. Salamanca: Comunicación Social, 66-88. 


\section{Authors' biography with Photo}

\section{Carmen Marta Lazo}

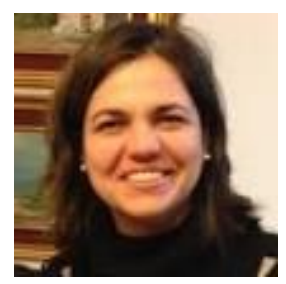

Dr. Carmen Marta-Lazo is an Associate Professor of Audiovisual Communication and Advertising at University of Zaragoza. She is the Principal Investigator of the Research Group on Digital Information and Communication (GICID). Dr. Marta-Lazo teaches courses on Radio and TV News Genres, as well as Communication Studies. She is also a member of the Multimedia Commission at the Spanish Conference of University Presidents as well as the Director of the college radio station Radio.unizar.es. Her research interests include media education, social media, audiences and interactions.

\section{María José Pérez Serrano}

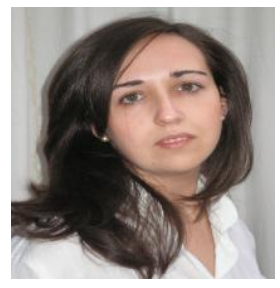

María José Pérez Serrano (Ciudad Real, 1979) has a degree in Journalism and doctorate in Information Sciences from the Complutense University of Madrid, and she has a MBA, with specialization in the area of financial management and corporate high management. Her doctoral thesis has earned the PhD Extraordinary Award of the academic year 2006-2007.

She has belonged, among others, the faculty of the School of Communication at the Pontifical University of Salamanca and Institute of Postgraduate and Continuing Education at the Universidad Pontificia de Comillas (ICADE) and she works in the Department of Journalism (Media Business) of the Complutense University of Madrid.

Her experience and scientific production is linked to the study of media business and, specifically, the media concentration and its influence on pluralism, but it is also remarkable research and information, concern in the field of methodology and didactics communication sciences and especially in the economic and business media.

She has developed academic stays at international universities and she is the author of articles and papers in scientific fields mentioned above, and she is part of research groups and doctoral dissertation. Among others, Maria Jose Perez Serrano is a member of the Spanish Association of Communication Research $(A E-I C)$ and, since its foundation, the European Media Management Education Association (EMMA).

\section{Juan Pablo Artero Muñoz}

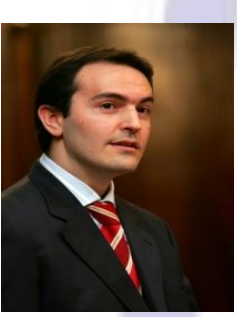

Juan P. Artero (Zaragoza, 1979) is an Associate Professor of Journalism at University of Zaragoza, Spain. He attended a BA in Audiovisual Communication at University of Navarra (2001), a MSc in Management at City University London (2005) and a PhD in Media Management at University of Navarra (2006). He also holds a BA in Political Science from UNED (2001). He has been a visiting fellow at the Institute for Media and Entertainment (2004) and Fordham University (2007), both in New York City. Since then, he has taught Media Management and Structure of Media Industries at University of Navarra and University of Zaragoza. His research interest are focused on competition, strategy and quality in media environments. He has published articles in Spanish and English at journals such as Comunicación y Sociedad, Sphera Publica, Palabra Clave, Observatorio, Telos, ZER, Doxa, Quaderns del CAC, Journal of Spanish Language Media or Journal of Applied Journalism and Media Studies. Books and book chapters written by him have been published at houses like Deusto, Fragua, Eunsa, Ulzama, Ariel, CEU, Comunicación Social, Routledge, Media $\mathrm{XXI}$ or Palgrave MacMillan. He is also an active member of the European Media Management Education Association and the World Media Economics and Management Conference and has attended scientific meetings in more than 25 countries. 